\title{
PENINGKATAN KOMPETENSI SANTRI PONPES MELALUI WEB DESAIN E-MARKETING DI PONPES AL-INSAN KEROTEK KECAMATAN CIBEBER KOTA CILEGON BANTEN
}

\author{
Arum Wahyuni Purbohastuti ${ }^{1}$, Muhammad Johan Widikusyanto², \\ Asmi Ayuning Hidayah ${ }^{3}$, Didik Aribowo ${ }^{4}$, Desmira ${ }^{5 *}$, Ratna Ekawati ${ }^{6}$ \\ ${ }^{123} \mathrm{D} 3$ Marketing, Manajemen, FEB, Untirta \\ 456Pendidikan Vokasional Teknik Elektro, FKIP, Untirta \\ Corresponding Author: *desmira@untirta.ac.id
}

\begin{abstract}
With these various advantages, it is necessary to further develop it to increase the income and welfare of the people in Islamic boarding schools which have the potential for managing economic empowerment with a large number of students. This of course requires assistance to the production and business management aspects of partners in each Islamic boarding school. Productive business institutions in Islamic boarding schools have complex institutional characteristics, so that the dynamics that occur between business actors greatly affect the performance of these productive businesses. This program is an empowerment activity for members of the "Insan Mandiri" Joint Business Group (KUB) of the Al Insan Kerotek Islamic Boarding School, Cibeber District, the output target to be achieved in this empowerment activity, namely the availability of intensively maintained productive efforts for Islamic boarding school students and the availability of the application of appropriate technology. simple activities in running productive businesses for joint business groups among students through web design training. The web design training method for students uses an open source web with simple steps for making it. It is hoped that this web design training can improve the competence of students in carrying out the promotion of the products of the students' work and business more optimally and are widely known by the public.

Keywords: training, web design, e-marketing, boarding school al insan cibeber
\end{abstract}

\begin{abstract}
Abstrak
Dengan berbagai keunggulan tersebut maka perlu dikembangkan lebih lanjut untuk meningkatkan pendapatan dan kesejahteraan masyarakat di pesantren yang berpotensi untuk mengelola pemberdayaan ekonomi dengan jumlah santri yang banyak. Hal ini tentunya membutuhkan pendampingan terhadap aspek produksi dan pengelolaan usaha mitra di masing-masing pondok pesantren. Lembaga usaha produktif di pesantren memiliki karakteristik kelembagaan yang kompleks, sehingga dinamika yang terjadi antar pelaku usaha sangat mempengaruhi kinerja usaha produktif tersebut. Program ini merupakan kegiatan pemberdayaan bagi anggota Kelompok Usaha Bersama (KUB) “Insan Mandiri” Pondok Pesantren Al Insan Kerotek Kecamatan Cibeber, target output yang ingin dicapai dalam kegiatan pemberdayaan ini yaitu tersedianya sarana produktif yang dipelihara secara intensif. upaya santri pesantren dan ketersediaan aplikasi teknologi tepat guna. kegiatan sederhana dalam menjalankan usaha produktif untuk kelompok usaha bersama antar mahasiswa melalui pelatihan desain web. Metode pelatihan desain web untuk siswa menggunakan web open source dengan langkah-langkah pembuatannya yang sederhana. Diharapkan dengan adanya pelatihan web design ini dapat meningkatkan kompetensi mahasiswa dalam melaksanakan promosi produk hasil karya dan bisnis mahasiswa secara lebih optimal dan dikenal luas oleh masyarakat luas.
\end{abstract}

Kata Kunci : pelatihan, web desain, e-marketing, ponpes al insan cibeber

@2021 Penerbit PS2PM FISIPKUM UNSERA

Segala bentuk plagiarisme dan penyalahgunaan hak kekayaan intelektual akibat diterbitkannya artikel pengabdian masyarakat ini sepenuhnya menjadi tanggung jawab penulis

Arum Wahyuni Purbohastuti, dkk., Peningkatan Kompetensi Santri Ponpes Melalui Web Desain E-Marketing Di Ponpes Al-Insan Kerotek Kecamatan Cibeber Kota Cilegon Banten 


\section{PENDAHULUAN}

Seiring perkembangan zaman, bisnis ritel mengalami perkembangan yang cukup pesat, khususnya di Indonesia. Hal ini ditandai dengan makin banyaknya bisnis ritel tradisional yang melakukan pembenahan diri menjadi bisnis ritel modern, maupun bisnis ritel modern yang baru lahir. Ritel merupakan keseluruhan aktivitas bisnis yang terkait dengan penjualan dan pemberian layanan kepada konsumen untuk penggunaan yang sifatnya individu sebagai pribadi dan keluarga. Pengelolaan bisnis ritel tidak sekedar hanya membuka toko dan mempersiapkan barang-barang yang lengkap, tetapi lebih dari itu. Pengelolaan bisnis ritel harus melihat dan mengikuti perkembangan teknologi pemasaran agar dapat berhasil dan mempunyai keunggulan bersaing (Respatiningsih, 2018)

Studi tentang hubungan agama atau nilai-nilai spiritualitas yang dianut dengan aspek ekonomi memang telah banyak dilakukan dan menunjukkan bahwa diantara keduanya terdapat hubungan yang signifikan. Nilai-nilai spiritualitas yang dianut, diyakini dan dipahami ini telah mendorong orang tersebut untuk memiliki etos kerja dan kegairahan atau semangat kerja, sehingga dari etos kerja yang dimiliki tersebut dia memiliki jiwa kewirausahaan dan kemandirian (Muttaqin, 2011)

Seiring dengan pentingnya upaya sebuah penelitian untuk mengevaluasi aktivitas atau praktek ekonomi umat Islam (individu atau masyarakat) yang mempunyai kegiatan usaha, maka dalam penelitian ini peneliti mencoba untuk menelusuri aktivitas perekonomian masyarakat Indonesia, yaitu kelompok masyarakat (social group) yang secara definitif sudah dianggap sebagai kriteria muslim. Begitu juga dengan aktivitas perekonomian yang mereka jalankan. Kelompok masyarakat (social group) tersebut adalah masyarakat pesantren dengan mengambil studi kasus di 
pondok pesantren (ponpes) Al Insan

Kota Cilegon Banten.

Ponpes memegang peranan kunci sebagi motivator, inovator, dan dinamisator masyarakat (Kedungkandang dan Saroh, nd). Hubungan interaksionis-kultural antara ponpes dengan masyarakat menjadikan keberadaan dan kehadiran institusi ponpes dalam perubahan dan pemberdayaan masyarakat menjadi semakin kuat (Ningsih, 2017). Namun demikian, harus diakui belum semua potensi besar yang dimiliki ponpes tersebut terkait dengan kontribusi ponpes dalam pemecahan masalahmasalah sosial ekonomi umat.

Dengan berbagai keunggulan yang ada di ponpes, perlu lebih dikembangkan untuk meningkatkan pendapatan dan kesejahteraan masyarakat di ponpes yang memiliki potensi akan pengelolaan pemberdayaan ekonomi dengan jumlah santri yang banyak. Hal ini tentunya memerlukan pendampingan terhadap aspek produksi dan manajemen usaha mitra yang ada di setiap ponpes.

Ponpes dengan basis santri yang beragam merupakan sebuah potensi pemberdayaan ekonomi umat yang tiada ternilai. Persoalan yang mendasar yang dihadapi kalangan santri maupun pengurus ponpes adalah bagaimana menciptakan kesinambungan antara pembelajaran santri terhadap ilmu agama yang sejalan dengan usahausaha produktif terkait dibidang ketahanan pangan dengan menjalankan salah satu usaha produktif bagi kalangan santri di ponpes. Pembelajaran tentang usaha produktif tentunya dibutuhkan kerjasama pengelolaan secara konsisten dan berkelanjutan.

Kelembagaan usaha produktif di ponpes memiliki karakteristik kelembagaan yang kompleks, sehingga dinamika yang terjadi antar pelaku usaha sangat mempengaruhi kinerja usaha produktif ini. Diantaranya terkait struktur pasar dan kelembagaan, seperti, tidak adanya 
kestabilan harga baik input maupun output, terutama tingginya biaya pakan dan bibit, serta keterbatasan ketersediaan bahan baku. Hal ini disebabkan oleh sangat bergantungnya usaha produktif kepada mitra terkait yang ada.

Pesatnya persaingan bisnis saat ini menuntut pelaku bisnis untuk selalu mengikuti perkembangan pasar maupun keinginan dari pasar. Kotler (1998) mengemukakan bahwa pasar terdiri dari semua pelanggan potensial yang memiliki kebutuhan dan keinginan tertentu serta mau dan mampu turut dalam pertukaran untuk memenuhi kebutuhan atau keinginan itu. Suatu perusahaan dalam menjalankan aktivitasnya harus efektif menjalankan konsep pemasaran agar keuntungan yang diharapkan dapat terealisasi dengan baik. Ini menandakan bahwa kegiatan pemasaran dalam perusahaan harus dikoordinasi dan dikelola dengan cara yang lebih baik. Pemasaran merupakan suatu proses sosial dan manajerial yang membuat individu dan kelompok memperoleh apa yang mereka butuhkan dan inginkan lewat penciptaan dan pertukaran timbal balik produk dan nilai dengan orang lain (Kottler \& Amstrong, 2003).

Bidang bisnis dan perdagangan yang berkembang saat ini sangat terpengaruh dengan perkembangan teknologi informasi khususnya dalam penggunaan internet (Jauhari, 2010) Dengan adanya internet dan Information and Communication Technology (ICT), proses pemasaran dan penjualan dapat dilakukan kapan saja tanpa terikat ruang dan waktu (Jinling, dkk, 2009). Dengan kemampuan internet yang bisa mengirimkan berbagai bentuk data seperti teks, grafik, gambar, suara, animasi, atau bahkan video, maka banyak kalangan bisnis yang memanfaatkan teknologi ini dengan membuat homepage untuk mempromosikan usahanya.

Pemasaran produk unggulan ponpes melalui e-marketing dapat melayani banyak pembeli dalam waktu 
bersamaan dan pembeli juga tidak perlu antri untuk menunggu dilayani (Nugrahani, 2011). Oleh karena itu, santri ponpes mampu merancang website sebagai media promosi dan penjualan produk unggulan santri ponpes Al Insan Kerotek Kecamatan Cibeber Kota Cilegon Banten. Dengan adanya home page diharapkan dapat mempermudah home industry untuk menyebarkan informasi tentang produk unggulan santri ponpes yang diproduksi dan mempermudah transaksi penjualan dengan cara online.

Berdasarkan pra survey di lapangan dan hasil diskusi dengan Kelompok Usaha Bersama (KUB) di ponpes, maka dapat dirumuskan masalah prioritas yang perlu ditangani oleh KUB "Insan Mandiri" dengan pendamping dari perguruan tinggi yaitu:

1. Usaha produktif berupa digital marketing yang dilakukan oleh KUB "Insan Mandiri" masih bersifat tradisional sehingga hasilnya belum optimal.
2. Kurangnya pengetahuan anggota kelompok tentang digital marketing yang dapat diandalkan.

3. Kurangnya kemampuan anggota kelompok untuk mengadopsi teknolgi tepat guna untuk meningkatkan usaha produktif berbasis pondok pesantren dan menurunkan tingkat mortalitas.

4. Anggota kelompok melakukan proses produksi usahanya tanpa ada recording sehingga kegiatankegiatan yang dilakukan tanpa data yang akurat karena hanya berdasarkan ingatan anggota kelompok selain itu kurangnya pengetahuan mengenai teknologi pemasaran.

Dari terselenggaranya kegiatan program ini, beberapa hal yang dapat dicapai dengan memenuhi indikator sebagai berikut :

Out-Put Untuk Santri.

- Adanya kesadaran dari santri dan pengelola Pondok Pesantren dalam memanfaatkan teknologi ICT.

- Menjadi solusi terbaik untuk 
melakukan

inovasi

mengembangkan web desain untuk

sarana promosi produk unggulan

dan karya santri ke dunia luar.

\section{METODE PELAKSANAAN}

Jenis metode pelaksanaan pada pengabdian masyarakat ini adalah menggunakan metode penelitian deskriptif. Metode deskriptif dapat diartikan sebagai prosedur pemecahan masalah yang diselidiki dengan menggambarkan keadaan subjek atau objek dalam penelitian dapat berupa orang, lembaga, masyarakat dan yang lainnya yang pada saat sekarang berdasarkan faktafakta yang tampak atau apa adanya. Metode deskriptif adalah suatu metode yang digunakan untuk menggambarkan atau menganalisis suatu hasil penelitian tetapi tidak digunakan untuk membuat kesimpulan yang lebih luas (Sugiyono, 2010). Dapat dikatakan bahwa penelitian deskriptif merupakan penelitian yang berusaha mendeskripsikan suatu gejala, peristiwa yang terjadi pada saat sekarang atau masalah aktual.

Metode deskriptif di sini menggunakan pendekatan kualitatif yang merupakan metode yang berlandaskan pada filsafat post positivisme, digunakan untuk meneliti pada kondisi objek yang alamiah, dimana peneliti adalah sebagai instrumen kunci, pengambilan sampel sumber data dilakukan secara purposive, teknik pengumpulan data dengan gabungan, analisis data bersifat induktif/kualitatif dan hasil penelitian kualitatif lebih menekankan makna dari pada generalisasi (Sugiyono, 2010).

Pengambilan subjek penelitian ditentukan secara purposive. Purposive sendiri mempunyai arti disengaja, yangartinya bahwa pengambilan subjek dilakukan berdasarkan adanya tujuan tertentu yang ingin dicapai bukan didasarkan pada sistem strata, sistem random maupun sistem yang lainnya. Purposive merupakan teknik 
penentuan subjek penelitian dengan pertimbangan khusus sehingga layak dijadikan subjek. Sumber yang dapat memberikan informasi dipilih secara purposive bertalian dengan purpose atau tujuan tertentu. Oleh karena itu, subjek yang diteliti akan ditentukan langsung dan berkaitan dengan masalah dan tujuan dari penelitian.

Oleh karenanya agar tidak sangat subyektif, peneliti harus punya latar belakang pengetahuan tertentu subjek yang dimaksud agar benar-benar bisa mendapatkan subjek yang sesuai dengan persyaratan atau tujuan penelitian (memperoleh data yang akurat). Subjek dipilih berdasarkan pertimbangan tertentu dengan tujuan untuk memperoleh subjek yang memiliki karakteristik yang dikehendaki.

\section{Khalayak Sasaran}

Proses rekruitmen peserta pelatihan dilakukan dengan cara:
- Sosialisasi dan survey langsung pada lokasi yang akan menjadi sasaran dari kegiatan ini.

- Bekerja sama dengan mitra Ponpes Al Insan dan melakukan pendampingan serta sosialisasi bersama santri terkait pemanfaatkan teknologi ICT untuk pengembangan web desain sebagai sarana promosi produk unggulan santri dengan indikator-indikator yang telah ditentukan.

\section{Kriteria Peserta Pelatihan}

- Santri ponpes Al Insan yang telah memiliki produk unggulan untuk dipromosikan melalui web. Materi dalam pelatihan web desain ini meliputi sebagai berikut: 
Tabel 1. Materi Pelatihan

\begin{tabular}{|c|c|c|}
\hline Sesi & Materi & Media \\
\hline $\mathrm{I}$ & $\begin{array}{l}\text { Konsep Dasar } e^{-} \\
\text {marketing, Internet dan } \\
\text { Aplikasi Website }\end{array}$ & $\begin{array}{l}\text { Infokus, } \\
\text { laptop }\end{array}$ \\
\hline II & $\begin{array}{l}\text { Pembelajaran dasar } \\
\text { pembuatan web } \\
\text { melalui Blog }\end{array}$ & $\begin{array}{l}\text { Infokus, } \\
\text { laptop }\end{array}$ \\
\hline
\end{tabular}

Pelatihan dilaksanakan di Aula

Ponpes Al Insan Kerotek Kecamatan

Cibeber Kota Cilegon Banten selama 2 sesi dan tiap sesi dialokasikan selama 90 menit dengan perincian sebagai berikut :

- 30 menit : Materi Pelatihan

- 60 menit : Diskusi, tanya jawab dan latihan

Metode analisis data yang digunakan dalam penelitian ini adalah analisis data Induktif. Analisis induktif ini digunakan untuk menilai dan menganalisis data yang telah difokuskan tentang peranan pondok pesantren dalam meningkatan pemberdayaan produk-produk unggulan dari santri. Analisis induktif ini peneliti gunakan dengan cara menganalisis hal-hal yang khusus untuk selanjutnya ditarik kesimpulan yang objektif.

\section{HASIL DAN PEMBAHASAN}

Keberhasilan

pelaksanaan program pengabdian masyarakat ini dilihat dari dua tolok ukur sebagai berikut :

1. Respons positif dari peserta pelatihan : respons peserta pelatihan akan diukur melalui observasi selama pelatihan berlangsung dan dengan memberikan kesempatan kepada peserta yang menyangkut kesan, saran, kritik dan usulan peserta pelatihan terhadap program pengabdian masyarakat ini.

2. Meningkatnya keterampilan peserta setelah mendapat pelatihan : keterampilan peserta pelatihan akan diobservasi saat pelatihan melalui demonstrasi pembuatan web yang telah ditentukan.

Selama pelaksanaan program pelatihan ini, mulai dari tahap persiapan sampai pelaksanaannya, dapat kami sampaikan temuan-temuan sebagai berikut : 
1. Antusiasme santri dan pengelola ponpes Al Insan sangat tinggi, menyambut dengan baik tawaran kerjasama sebagai mitra dalam program pengabdian masyarakat ini. Pihak mitra berharap program ini bisa dilaksanakan secara reguler dan berkala di tahun-tahun selanjutnya.

2. Materi pelatihan yang diberikan sangat sesuai dengan kebutuhan untuk pengembangan dan pembuatan web desain sebagai sarana efektif dan mempromosikan produk dan karya unggulan santri, terlihat dari efektifitas dan tingkat kesulitan materi pelatihan yang tidak terlalu memberatkan bagi para peserta pelatihan. Materi ini benar-benar memberikan penyegaran dan penambahan wawasan atas program-program pengabdian masyarakat di luar yang telah mereka dapatkan sebelumnya.

3. Situasi dan kondisi pelatihan sangatlah kondusif dan memberikan kenyamanan bagi peserta pelatihan. Hal ini tentu saja di dukung dengan fasilitas sarana dan prasarana yang sangat memadai dari penyelenggara bersama mitra kegiatan pengabdian masyarakat

4. Potensi dan kemampuan pembelajaran dari peserta pelatihan dari santri dan pengelola ponpes Al Insan terlihat baik, terbukti dari hasil observasi yang dilakukan selama pelatihan.

Pelatihan pada pengabdian masyarakat di Ponpes Al Insan ini di awali dengan penyampaian materi oleh Tim Narasumber Fakultas Ekonomi dan Bisnis (FEB) Universitas Sultan Ageng Tirtayasa (Untirta) mengenai pengenalan konsep e-marketing dan dasar tentang internet serta implementasi web bagi sarana media promosi produk-produk unggulan bagi santri dan pengelola ponpes $\mathrm{Al}$ Insan. 


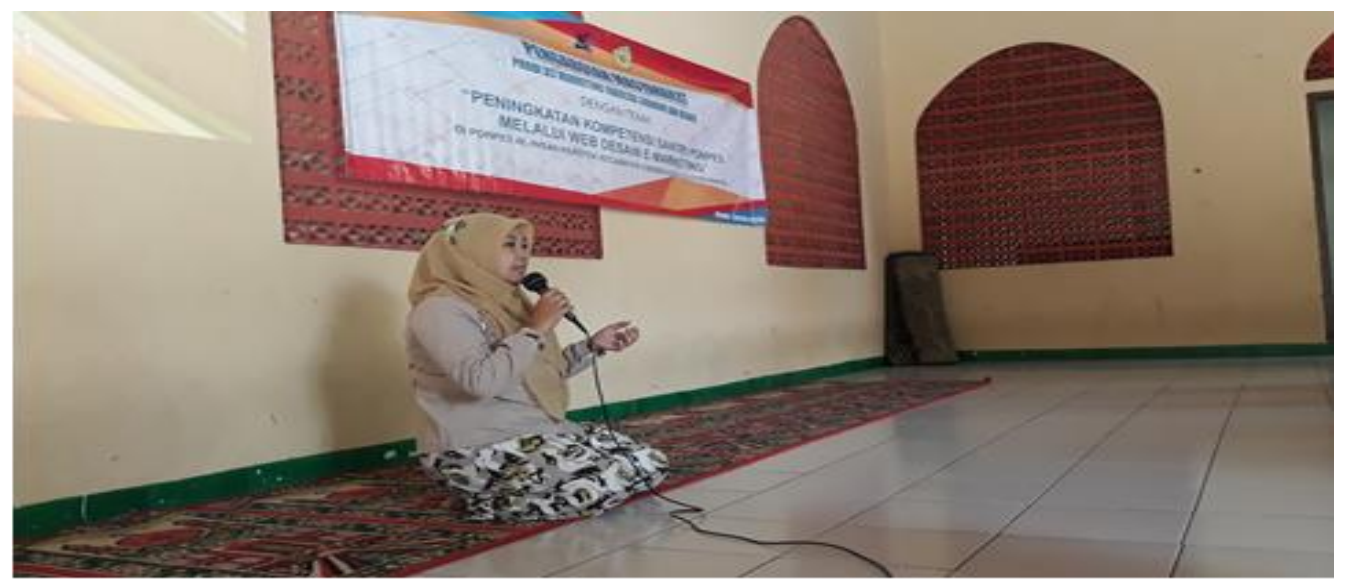

Gambar 1. Penyampaian materi pertama tentang e-marketing, Internet dan Aplikasi Website

Konsep mengenai emarketing adalah proses untuk mencapai tujuan pemasaran melalui pengunaaan teknologi komunikasi elektronik. Aplikasi e-marketing cocok digunakan pada ponpes yang ingin memperluas pasarnya dengan produk unggulan dan karya yang dihasilkan oleh santri ponpes. Dengan adanya aplikasi web ini dengan ditunjang oleh sarana internet dan perangkat ICT yang dimiliki oleh ponpes Al Insan diharapkan dapat menjangkau lebih banyak lagi konsumen atas produk unggulan dan karya santri ponpes Al Insan.

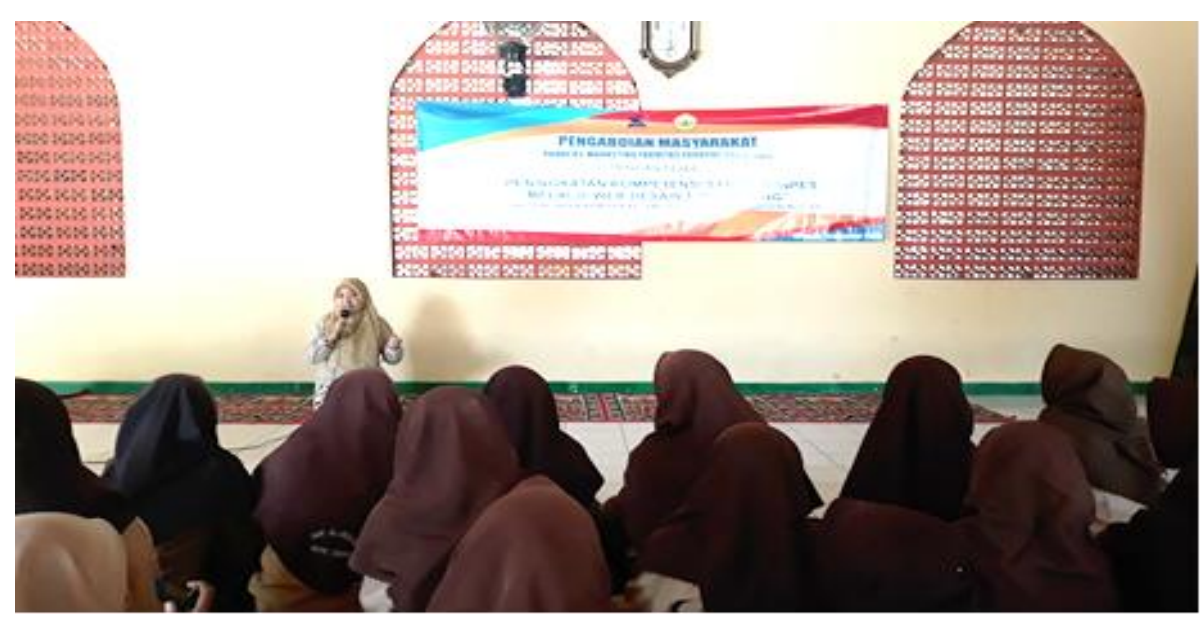

Gambar 2. Antusiasme santri ponpes Al Insan terhadap e-marketing, internet web desain

Arum Wahyuni Purbohastuti, dkk., Peningkatan Kompetensi Santri Ponpes Melalui Web Desain E-Marketing Di Ponpes Al-Insan Kerotek Kecamatan Cibeber Kota Cilegon Banten 
Santri ponpes $\mathrm{Al}$ Insan

Kerotek Kecamatan Cibeber

Kota Cilegon Banten merespon

dengan antusias terhadap materi

yang disampaikan oleh tim
Hal ini terbukti dengan tingkat kehadiran yang memenuhi aula ponpes $\mathrm{Al}$ Insan yang dipenuhi oleh santri disela-sela aktifitas rutin harian santri di ponpes. narasumber dari FEB Untirta.

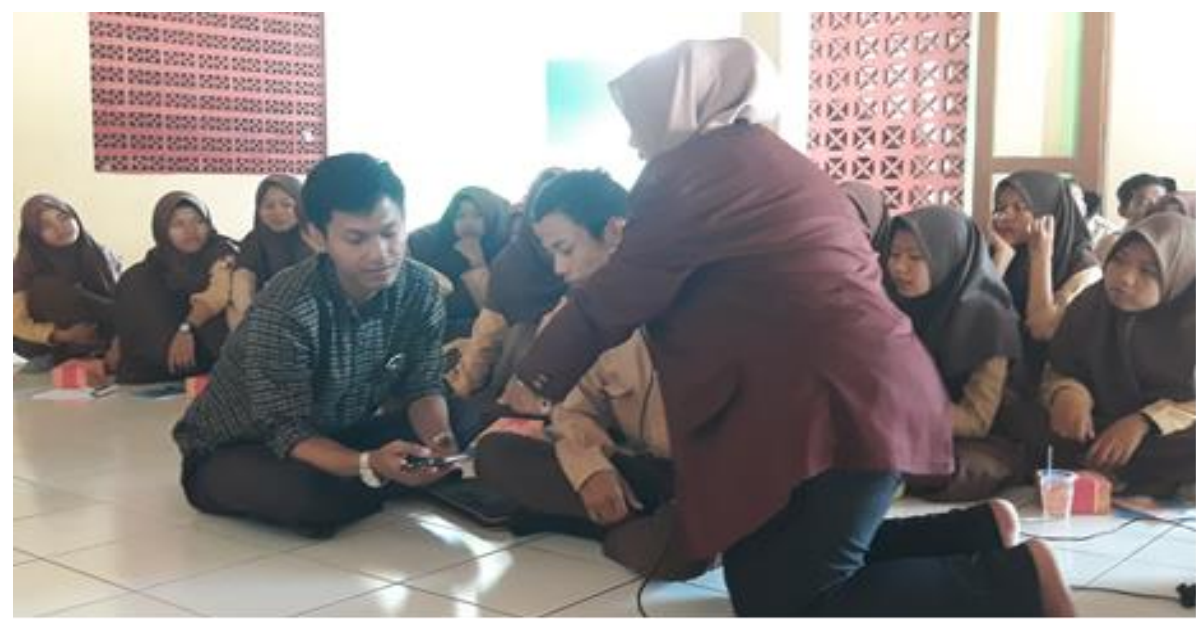

Gambar 3. Santri berinteraktif dalam melakukan praktik pembuatan web desain melalui perangkat smartphone'

\section{Aktifitas pelatihan}

perancangan dan pembuatan

web desain sebagai sarana

promosi produk unggulan dan

karya produktif santri dibekali

dengan pengetahuan dan materi

sebagai berikut :

1. Pengenalan website

2. Jenis - jenis website
3. Pembelajaran

dasar pembuatan website dengan $b \log$

Adapun langkah-langkah untuk membuat website yang diperkenalkan kepada santri ponpes Al Insan dengan menggunakan blog yaitu sebagai berikut : 
1. Buka http://www.blogger.com

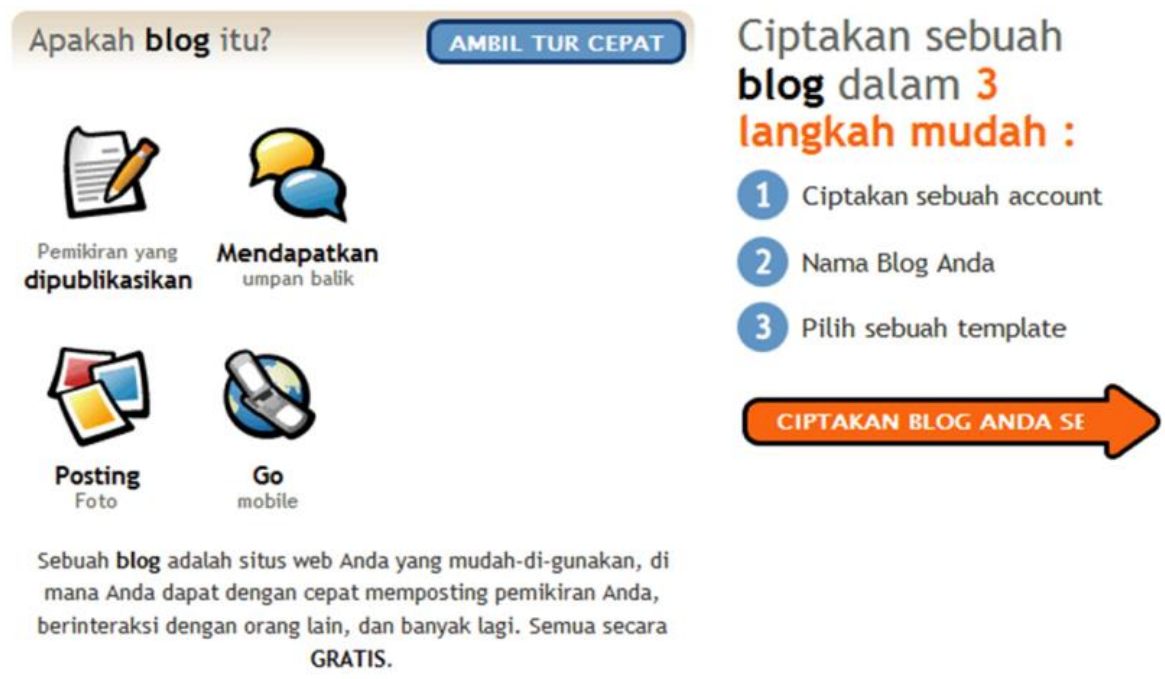

\section{Mengisi Formulir Pendaftaran}

(1) Ciptakan sebuah Account Google Google

Proses ini akan menciptakan account Googte yang dapat Anda gunakan pada layanan Google lainnya-
Jika Anda sudah memiliki sebuah account Google mungkn dari Gmail, Google Groups, atau Orkut, silakan Slogin terlebilh dahulu

Alamat email

(harus sudah ada)

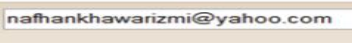

Gnda akan mengzumakan alambt Wranan Googite tainnya. Kamit tidak akan pernah membaginy

Masukkan sebuah passwor
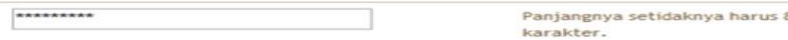

Ketik ulang sand

Nama Tampilan

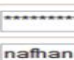

Verifikasi Kata

nafhan

consr

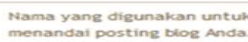

ketikkan karakter yami And
that pada gambar ke kiri.
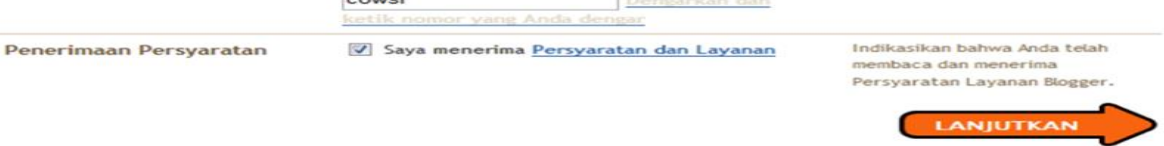

3. Memberi Nama Blog

2. Beri nama blog Anda

\begin{tabular}{ll|ll}
\hline Judul Blog & My blog is My Favourite & & $\begin{array}{l}\text { Masukkan sebuah judul } \\
\text { untuk blog Anda. }\end{array}$ \\
\hline Alamat Blog (URL) & 3 $\begin{array}{ll}\text { http://myfaveblog } \\
\text { Cek Ketersedian }\end{array}$ & .blogspot.com & $\begin{array}{l}\text { Anda dan yang lain akan } \\
\text { menggunakan ini untuk } \\
\text { membaca dan link ke blog }\end{array}$ \\
& & Anda.
\end{tabular}

ATAU

Setup Tingkat Lanjut

Ingin hosting blog Anda di tempat lain? Cobalah Setup Blog Tingkat Lanjut. Ini akan mengijinkan Anda untuk hosting blog Anda di tempat lain selain di Blogspot.

Arum Wahyuni Purbohastuti, dkk., Peningkatan Kompetensi Santri Ponpes Melalui Web Desain E-Marketing Di Ponpes Al-Insan Kerotek Kecamatan Cibeber Kota Cilegon Banten 


\section{Memilih Template}

2 Pilih sebuah template

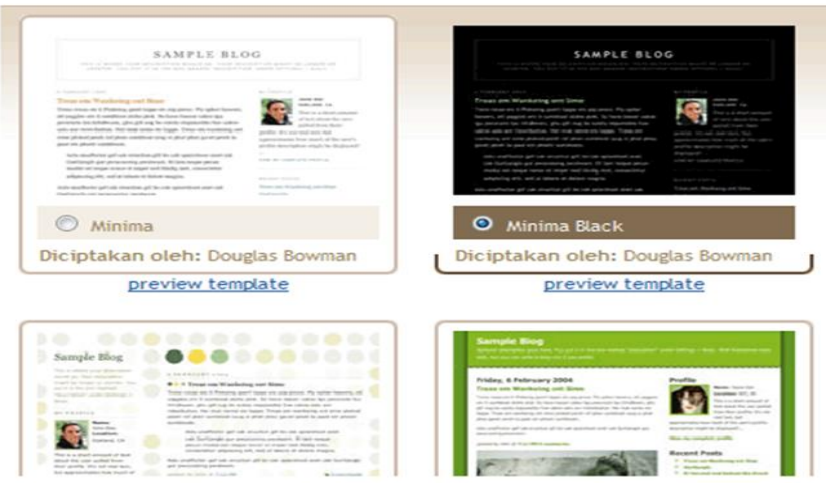

Pith tampilan kustom untuk blog Anda.

Anda bisa dengan

template nanti, at

bahlan nanit, atau

bahkan menciptak

kustom milik Anda

setelah blog Anda di

set up.

\section{Konfirmasi Bahwa Blog Sudah Tercipta}

Blog Anda telah diciptakan!

Kami telah menciptakan sebuah blog untuk Anda. Anda sekarang dapat menambah posting Anda,

menciptakan profil personal Anda, atau kustomisasi bagaimana blog Anda tertihat.

\section{MULAI POSTING}

\section{Menulis Posting}

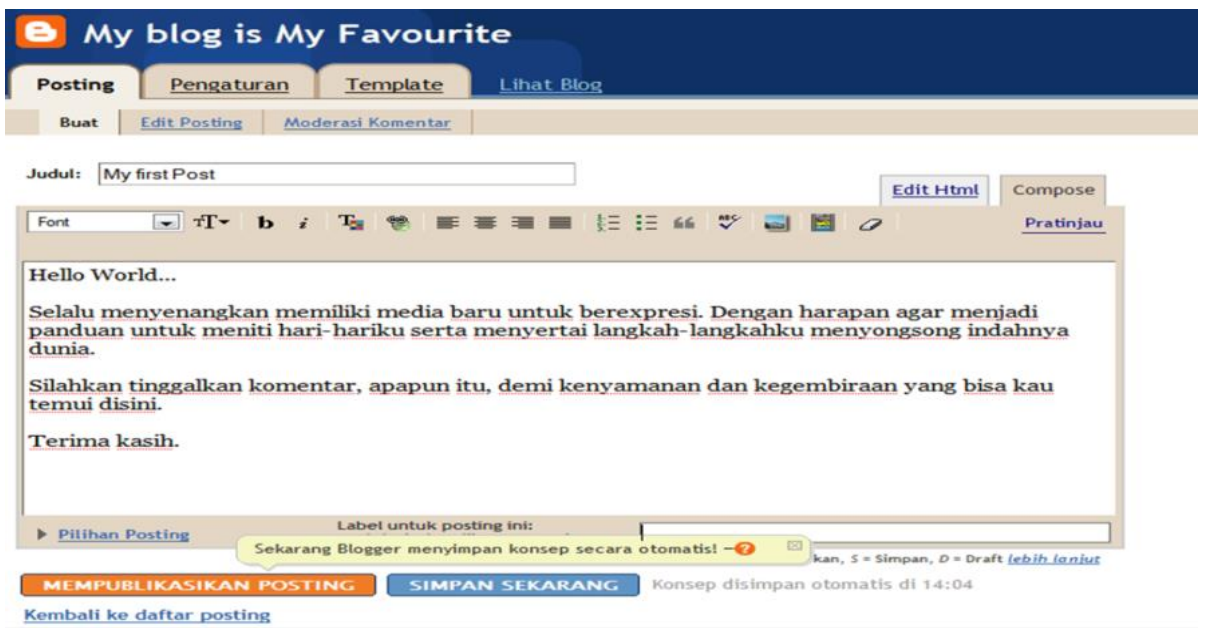

Arum Wahyuni Purbohastuti, dkk., Peningkatan Kompetensi Santri Ponpes Melalui Web Desain E-Marketing Di Ponpes Al-Insan Kerotek Kecamatan Cibeber Kota Cilegon Banten 


\section{Konfirmasi Posting Berhasil}

\section{Posting blog Anda berhasil diterbitkan! Lihat Blog g(ijended bro}

\section{Perlu untuk mengubahnya) Edit posting | Ciptakan sebuah post baru}

8. Tampilan Blog yang Baru Saja Tercipta

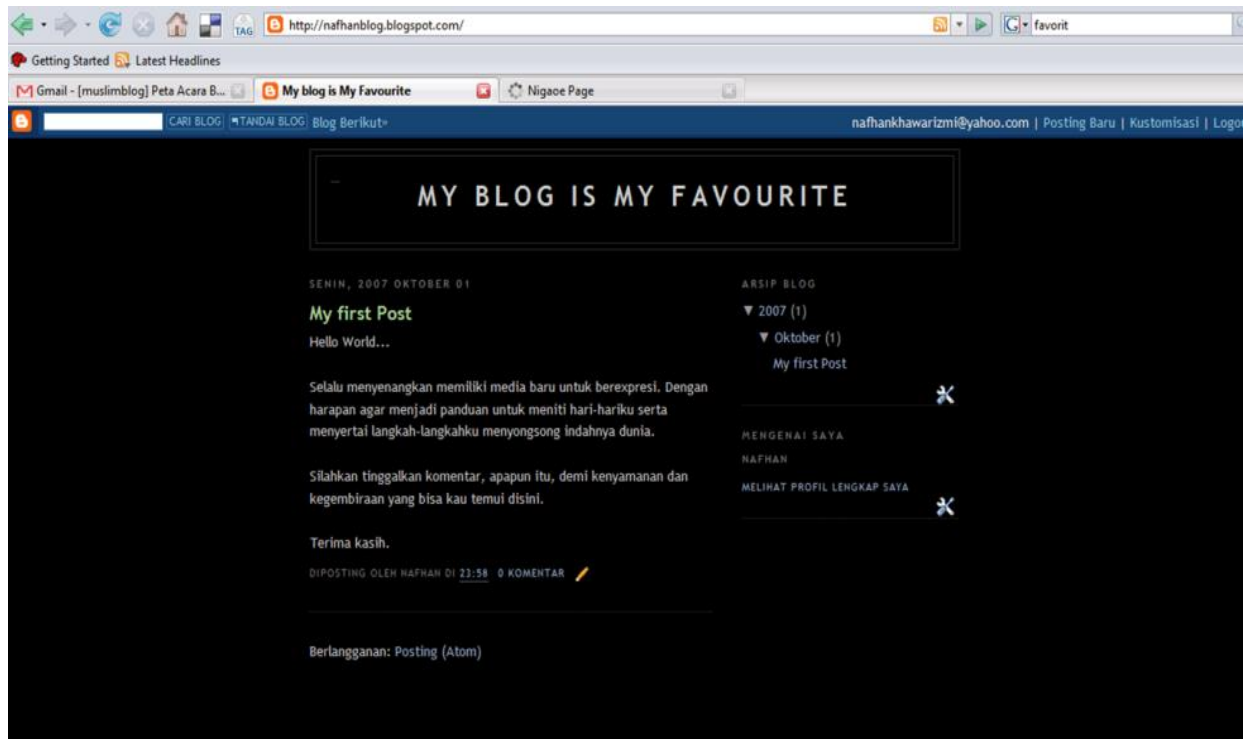

\section{Mengenal Elemen Halaman}

\section{B My blog is My Favourite}

Posting Pengaturan Template Lhat Elogs

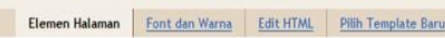

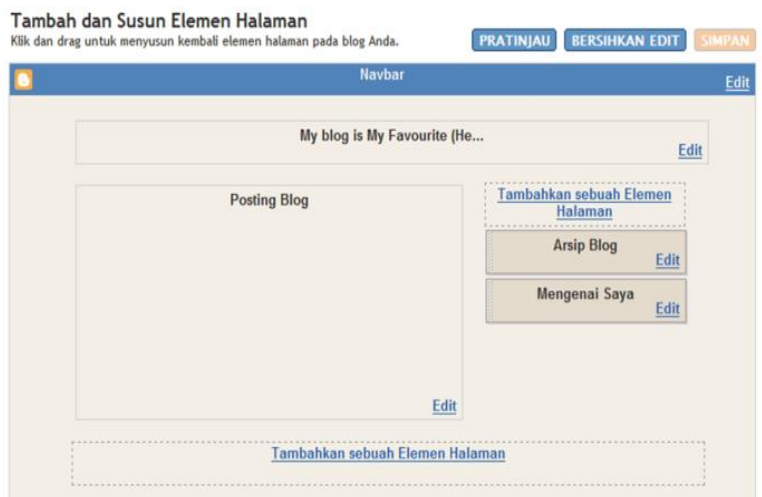

Arum Wahyuni Purbohastuti, dkk., Peningkatan Kompetensi Santri Ponpes Melalui Web Desain E-Marketing Di Ponpes Al-Insan Kerotek Kecamatan Cibeber Kota Cilegon Banten 
10. Memformat Warna (1)

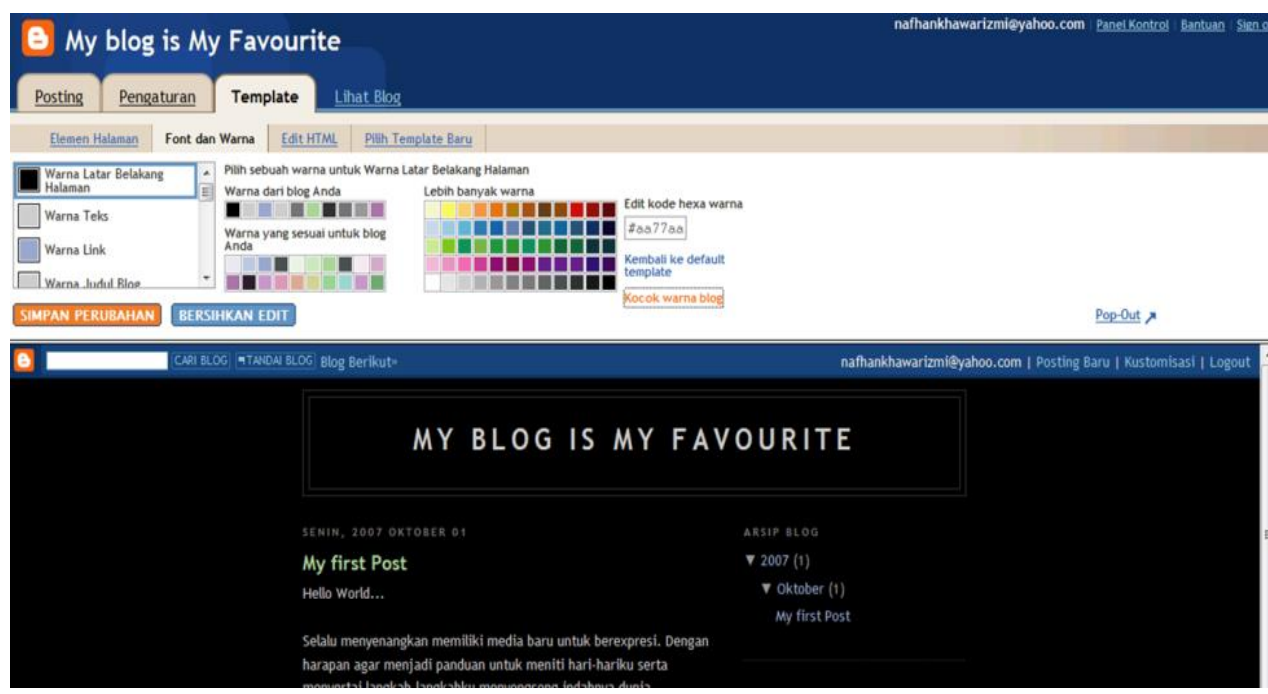

11. Memformat Warna (2)

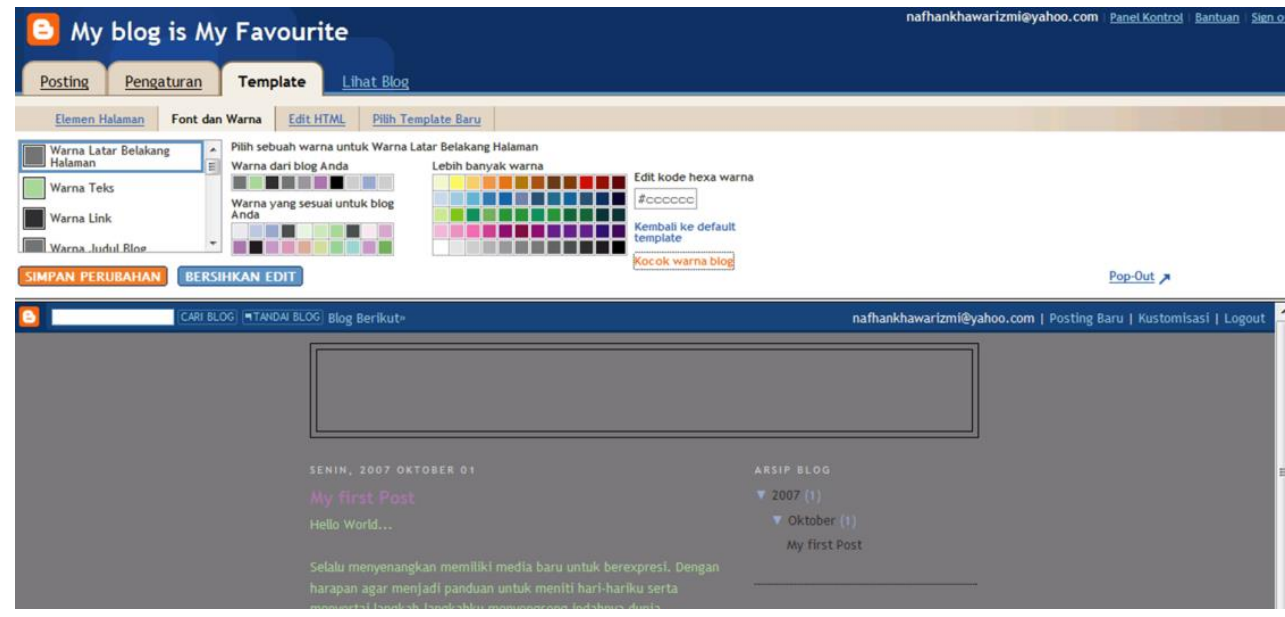

12. Memformat Jenis Huruf

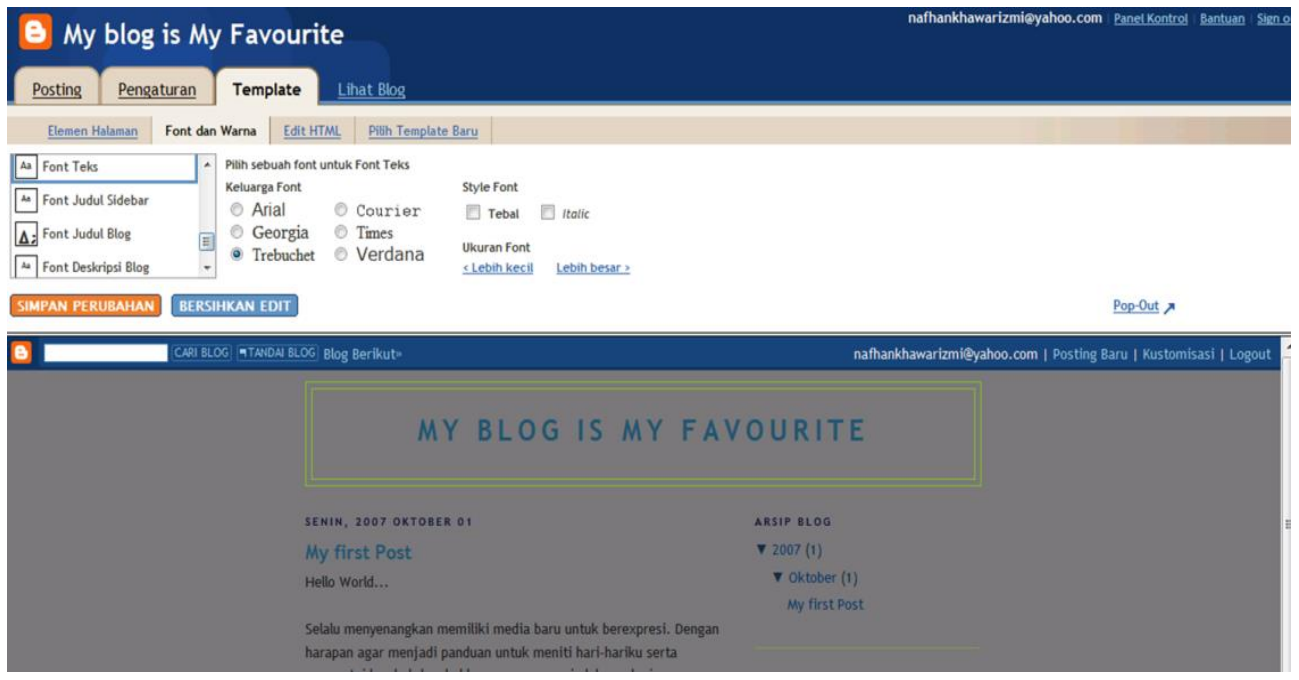

Arum Wahyuni Purbohastuti, dkk., Peningkatan Kompetensi Santri Ponpes Melalui Web Desain E-Marketing Di Ponpes Al-Insan Kerotek Kecamatan Cibeber Kota Cilegon Banten 
13. Halaman Edit HTML

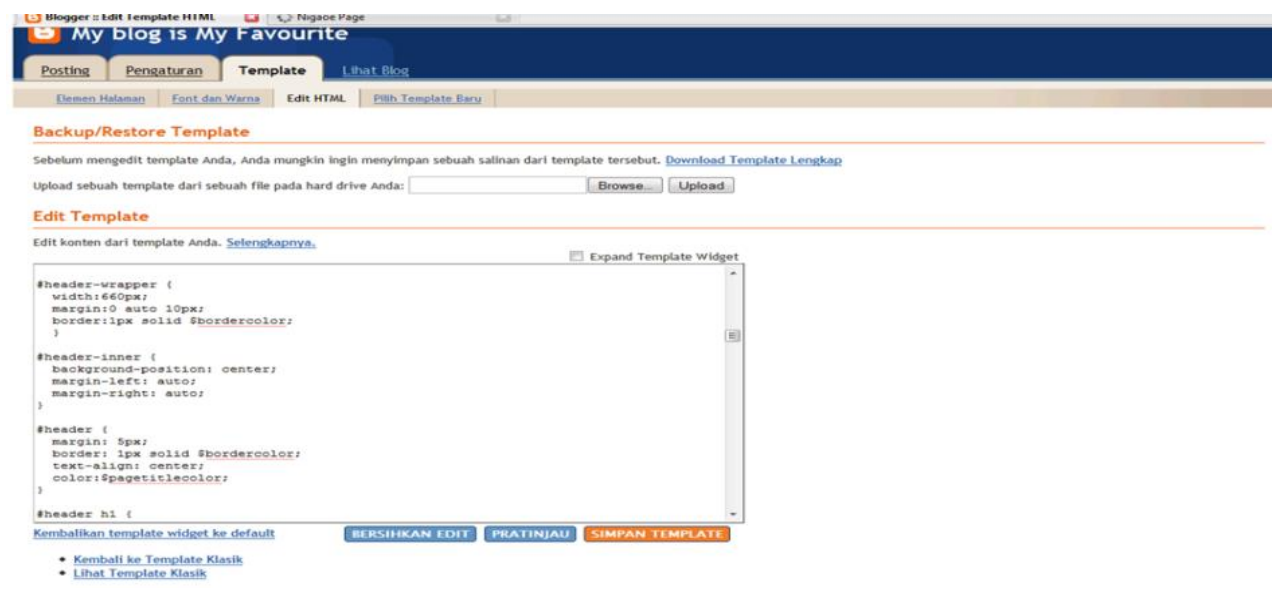

14. Memasang Header

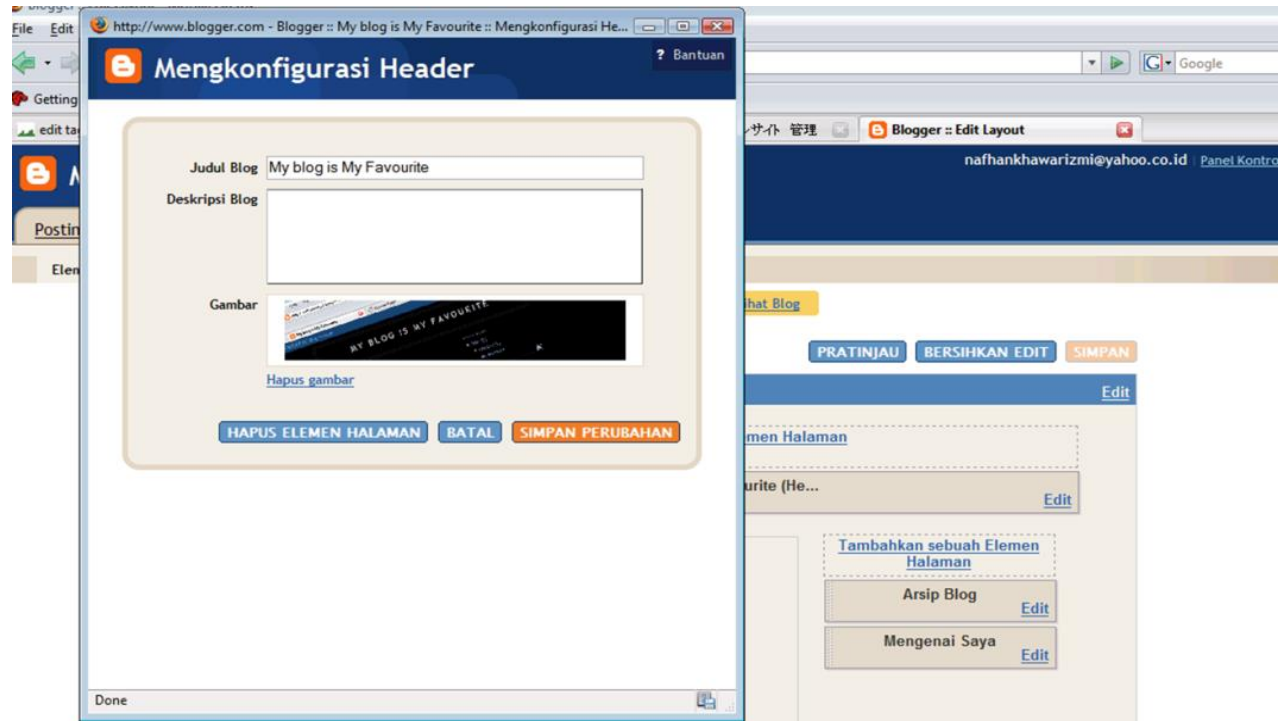

15. Blog Hasil Penyuntingan

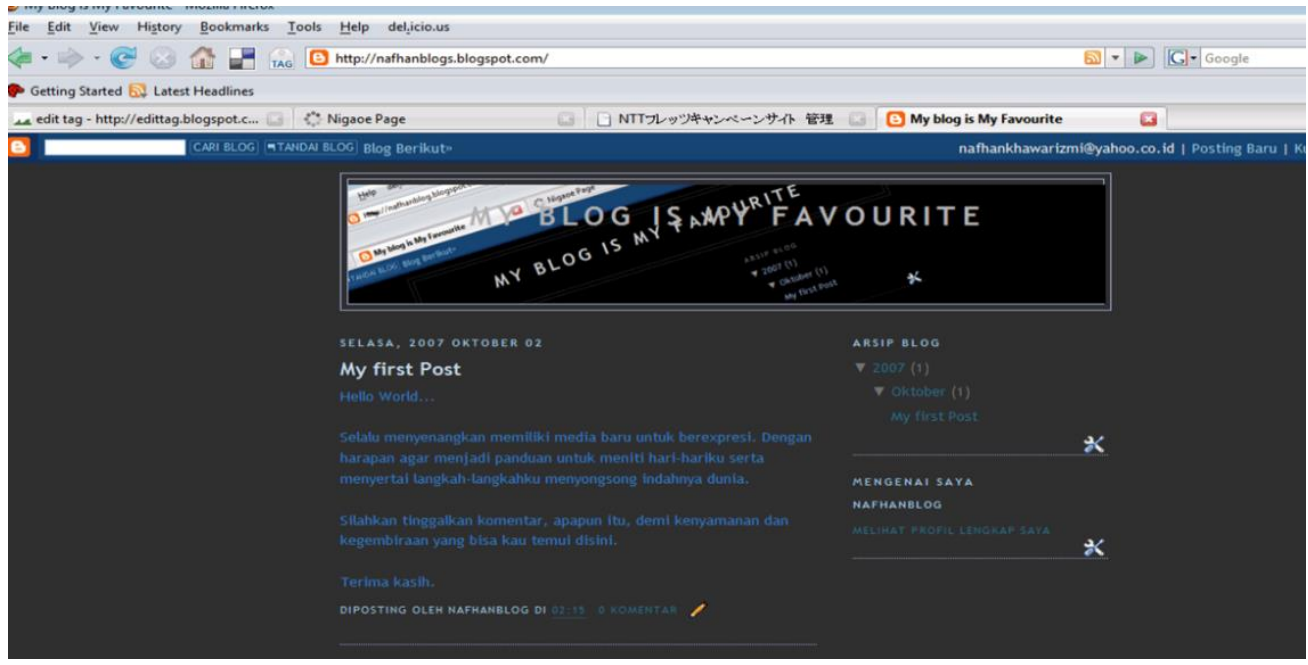

Arum Wahyuni Purbohastuti, dkk., Peningkatan Kompetensi Santri Ponpes Melalui Web Desain E-Marketing Di Ponpes Al-Insan Kerotek Kecamatan Cibeber Kota Cilegon Banten 


\section{SIMPULAN}

Dari beberapa hasil pengamatan dan percobaan pelatihan terhadap santri ponpes Al Insan diperoleh kesimpulan sebagai berikut ;

1. Santri dapat mengikuti pelatihan web desain ini dengan antusias dengan menunjukkan peran aktifnya dalam bertanya dan berdiskusi terhadap pengembangan web desain.

2. Santri ponpes dapat menghasilkan web desain dengan menggunakan blog yang digunakan dengan berbasis blog sebagai langkah pembelajaran dan pengembangan lebih lanjut ke depannya terhadap produk unggulan karya santri

\section{REFERENSI}

Hesti Respatiningsih.

2018.

Implementasi Manajemen

Kategori Dalam Manajemen

Ritel Modern.

Rizal Muttaqin. 2011. Kemandirian dan Pemberdayaan Ekonomi

Berbasis Pesantren. Jurnal

Ekonomi Syariah Indonesia.

Volume I, No.2 Desember 2011

Malang, Kedungkandang, and Siti Saroh. Pengembangan Model

Pendidikan Kewirausahaan

Dalam Meningkatkan Skill

Santri; Kasus Di Ponpes

Alhayatul Islamiyah. Susunan

Dewan Penyunting 6 (n.d.): 51.

Tirta Rahayu Ningsih. 2017.

Pemberdayaan Ekonomi

Pesantren Melalui

Pengembangan Sumber Daya

Lokal, Lembaran Masyarakat:

Jurnal Pengembangan

Masyarakat Islam3, no. 1 (2017): $57-78$.

Kottler, P. dan Amstrong P., 2003. Manajemen Pemasaran, Edisi 
terjemahan, Jakarta : Salemba.

Jauhari, J., 2010. Upaya Pengembangan

Usaha Kecil dan Menengah

(UKM) dengan Memanfaatkan

E-Commerce, Jurnal Sistem

Informasi, 2(1), 159-168.

Jinling, C., Tong, S., Chunan, L., and

Tao, S., 2009. Modeling E-

Commerce Website Quality with

Quality Function Deployment,

IEEE International Conference

on Deployment e-Business

Engineering.

Nugrahani, D.S., 2011. E-Commerce

untuk Pemasaran Produk Usaha

Kecil dan Menengah, SEGMEN

Jurnal Manajemen dan Bisnis, 1,

$1-16$.

Sugiyono, 2010, Metode Penelitian

Pendidikan Pendekatan

Kuantitatif, kualitatif, dan R\&D,

Alfabeta, Bandung.

http://www.kemenperin.go.id/artikel/1

8425/Tekan-Pengangguran,-

$\underline{\text { Pondok-Pesantren-Dipacu- }}$

Ciptakan-Pelaku-IKM

http://faktabanten.co.id/ponpes-al- insan-cilegon-dipercaya-kelolawarung-ritel-berbasis-wakaf/

http://faktabanten.co.id/pesantrensalafi-al-insan-cilegon-bisaubah-kotoran-ternak-jadibiogas/

-

